\title{
Xanthine oxidase activity regulates human embryonic brain cells growth
}

\author{
K. E. Danielyan, G. A. Kevorkian \\ H. Buniatian Institute of Biochemistry, NAS of Republic of Armenia \\ 5/1, P. Sevak Str., Yerevan, Republic of Armenia, 0014 \\ kristine_danielyan@biochem.sci.am
}

\begin{abstract}
Aim. Involvement of Xanthine Oxidase (XO; EC1.1.3.22) in cellular proliferation and differentiation has been suggested by the numerous investigations. We have proposed that XO might have undoubtedly important role during the development, maturation as well as the death of human embryos brain cells. Methods. Human abortion material was utilized for the cultivation of brain cells (E90). XO activity was measured by the formation of uric acid in tissue. Cell death was detected by the utility of Trypan Blue dye. Results. Allopurinol suppressed the $X O$ activity in the brain tissue $(0.12 \pm 0.02 ; 0.20 \pm 0.03$ resp., $p \leq 0.05)$. On day $12^{\text {th }}$ the number of cells in the culture treated with the Allopurinol at the early stage of development was higher in comparison with the Control $(2350.1 \pm 199.0 \mathrm{vs} 2123 \pm 96)$ and higher in comparison with the late period of treatment (1479.6 $\pm 103.8, p<$ $<0.05)$. In all groups, the number of the dead cells was less than in Control, indicating the protective nature of Allopurinol as an inhibitor of XO. Conclusions. Allopurinol initiates cells proliferation in case of the early treatment of the human brain derived cell culture whereas at the late stages it has an opposite effect.
\end{abstract}

Keywords: xanthine oxidase, human embryonic brain cells, proliferation, cell death

Introduction. Neuronal death during the processes of proliferation and cell migration is pronounced in embryonic developing brain [1].

It was demonstrated that in chick embryos, about $45 \%$ of the retinal ganglion cells are lost between E10 and E16 [2], whereas isthmo-optic nucleus loss is about $55 \%$ between E12 and E17 [3]. Neuronal death occurs at the time of the formation of connectivity with other neurons, during the development of the synapses.

The mechanism of reactive oxygen species production might be mediated due to the activity of the Xanthine Oxidase (XO; EC1.1.3.22). Activity of this enzyme might be similar at the number of diseases, including myocardial ischemia, stroke, chronic heart failure, hypertension, hypercholesterolemia, atherosclerosis, diabetes etc.

(C) Institute of Molecular Biology and Genetics, NAS of Ukraine, 2011
Furthermore, an involvement of XO in cellular proliferation and differentiation has been suggested [4]. Moreover, Moriwaki et al. demonstrated the presence of XO in brain, as well as in other organs, by the utility of immunochemical methods [4].

Taking into account that $\mathrm{XO}$ is responsible for the ROS formation its involvement into the delayed recovery of injured nerves in old rats as well as into tissue repair might be suggested [5].

We have proposed that $\mathrm{XO}$ might play undoubtedly important role during the cell growth, development, maturation as well as in death of human brain derived cell culture.

Materials and methods. Trypan Blue staining. A cell suspension was prepared in BSS (Hank's Balanced Salt Solution, Product No. H9269, «Sigma», USA). After all it was transfered $0.5 \mathrm{ml}$ of $0.1 \%$ Trypan Blue solution to a test tube and $0.3 \mathrm{ml}$ of BSS was added to 
$0.2 \mathrm{ml}$ of the cell suspension (dilution factor $=5$ ) and mixed thoroughly. The cell suspension-Trypan Blue mixture was kept for at least $5 \mathrm{~min}$ [6]. The cultured cells were trypsinized with $0.25 \%$ trypsine solution and collected from the plates. Cells were stained with the $2 \%$ Trypan Blue dye for visualization of the viable/non viable cells.

Cell culturing. All procedures with the utility of biomaterials were carried out in accordance with the Declaration of Helsinki. Human embryos were obtained from elective abortions with the informed consent of the women seeking abortion. Moreover, only fetuses with the age of formation no more than 12 weeks were used as a biomaterial [7].

Brains of the human embryos (E90) were withdrawn, and placed in Neurobasal medium (NB, prenatal, «Gibco Life Technologies», USA) containing $0.05 \%$ bovine serum albumin (BSA). The tissue was isolated and incubated at $37^{\circ} \mathrm{C}$ for $20 \mathrm{~min}$ in NB containing $0.05 \%$ BSA, $0.15 \%$ trypsine. The tissue was resuspended in fresh NB and mechanically disintegrated using a Pasteur pipette. The supernatant was discarded and the cell suspension resuspended in NB medium containing $1 \%$ BSA. This procedure was repeated 3 times. Human brain cells were collected $(1,000 \mathrm{rpm}$, $10 \mathrm{~min}$ ), washed and cultured at $37{ }^{\circ} \mathrm{C}, 5 \% \mathrm{CO}_{2}$ in $35 \mathrm{~mm}$ Petri dishes pre-coated with poly-L-lysine ( $« \mathrm{Sig}$ ma») containing $0.09 \% \mathrm{Na}_{2} \mathrm{HPO}_{4}, 1 \%$ glucose, $0.4 \%$ $\mathrm{KCl}, 0.06 \% \mathrm{KH}_{2} \mathrm{PO}_{4}, 0.4 \% \mathrm{MgSO}_{4} \times 7 \mathrm{H}_{2} \mathrm{O}$ and $0.001 \%$ gentamicin sulfate. A day later the medium was replaced by NB containing $2 \%$ B27-supplement («Gibco») and the cells' number was calculated on the days second and $12^{\text {th }}[8]$.

Xanthine Oxidase activity estimation by determination of the uric acid quantity in the brain tissue [9]. Xanthine and Allopurinol were incubated with the biological solution for one hour at $37{ }^{\circ} \mathrm{C}$, after the Specol 2000 estimated all the absorption at $660 \mathrm{~nm}$.

Homogenization of the human embryos brain. For $100 \mathrm{ml}$ of the buffer $0.87 \mathrm{~g} \mathrm{NaCl}, 0.06 \mathrm{~g} \mathrm{KH}_{2} \mathrm{PO}_{4}$, $0.09 \mathrm{~g} \mathrm{Na}_{2} \mathrm{HPO}_{4}, 5 \mathrm{mM} \mathrm{MgCl}$, $0.1 \mathrm{M}$ Tris aminomethane, $1 \mathrm{ml}$ of Triton $\mathrm{X} 100,200$ ug of Trypsine inhibitors, $0.001 \mathrm{M} \mathrm{KNaC}_{4} \mathrm{H}_{4} \mathrm{O}_{6} \times 4 \mathrm{H}_{2} \mathrm{O}$ were added. Glassglass homogenization was performed during $20 \mathrm{~min}$. The mixture was centrifuged at $G=8000$ for $20 \mathrm{~min}$. Supernatant was used for the experiments.

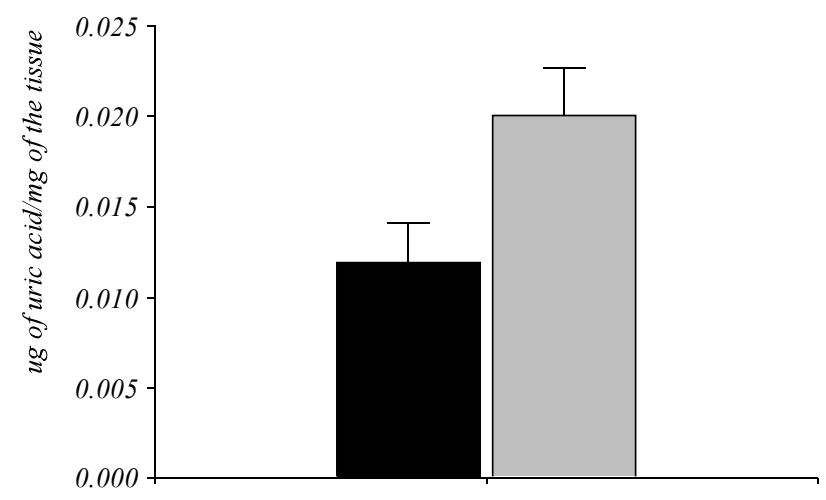

Fig. 1. Activity of XO in the human embryos brain. Grey column represents [XO] activity in the brain $(n=16)$; black column points to the suppressive abilities of Allopurinol. Here are represented standard errors of the mean and $\mathrm{p}<0.05$ calculated by $t$-student test

Microscopy. It was used Polarizing microscope Biolar PI (PZO, Poland; magnification $1.25 \times 40$ or $1.25 \times 20)$. The pictures were taken on $12^{\text {th }}$ day. Number of the cells was calculated by the utility of Pixcavator program, allowing authomatically to calculatate the size as well as the number of the cells.

Detection and quantification of proteins by Bradford. The protein content in samples was determined in the Specol 2000 (Poland) at $590 \mathrm{~nm} \mathrm{[10].}$

Statistics. We have used $t$-test (student) for pair comparison as well as ONE-WAY-ANOVA for estimation of the significance. The results were considered statistically significant when $p$ was lower or equal to 0.05 .

Results and discussion. The influence of Allopurinol on the activity of $X O$. We have measured the $\mathrm{XO}$ activity in the wide range of human embryos brains to determine whether there is any correlation between the activity and the age of the latter. According to our results there is no any difference. The activity of $\mathrm{XO}$, disclosed as the formation of total uric acid in the solution, was suppressed by $40 \%$ (Fig. 1). The black column represents an effect of Allopurinol whereas the grey one - the total activity of XO $(0.12 \pm 0.02 ; 0.20 \pm$ \pm 0.03 respectively, $p=0.05$ ) .

The second series of experiments devoted to examination of the XOR inhibitor effect in the cells culture. We used two types of XO inhibitor - Allopurinol. The cells obtained from human E12 embryonic brain were treated with Allopurinol in different concentrations (high and low) as well as in different time points $\left(1^{\text {st }}\right.$ to 
$6^{\text {th }}$ days - as the first period and $6^{\text {th }}$ to $12^{\text {th }}$ days - as the second period) to delineate the functional properties and the role of XO activity in the development and survival of the brain cells.

The results were very interesting. Allopurinol in low concentration during the first period of time did initiate the growth of cells $(2350.1 \pm 199.0)$, whereas during the second time period the same concentration of the inhibitor had the opposite influence and significantly reduced (1479.6 \pm 103.8$)$ the number of brain cells in the culture in comparison with the Control $(2123 \pm 96, \mathrm{p}<$ $<0.05$ ) and low dosage treatment during the early period $(p<0.05)$. The high concentration of Allopurinol had no significant effects $(1907.3 \pm 194.4 ; 1992 \pm 43)$ in comparison with the Control group (Fig. 2, see inset ).

It is interesting that all concentrations of Allopurinol at any stage of the cells growth and development decreased the cell death in comparison with the control in statistically significant way (control - $3538.33 \pm 356.61$; early stage of the treatment: low concentration of Allopurinol $-2385.20 \pm 389.13$, high $-1033.67 \pm 235.15$; late stage of the treatment: low concentration of Allopurinol $-389.80 \pm 66.80$, high $-876.67 \pm 221.78 ; \mathrm{p}<$ $<0.05$ between all groups $v_{s}$ Control (Fig. 3 , see inset).

Our experimental results demonstrated the XO presence in the developing human embryos brain. In accordance with the known data and our results its activity might be inhibited by Allopurinol.

It is well known that $\mathrm{XO}$ might initiate the formation of synapses and connections between the neuronal cells [4] and introduce regenerative or developmental activities.

On the other hand it might serve as a source initiating cells' death [11].

Thus, the same enzyme - XO - has a bifacial functional activity - death and proliferation.

In our experiments partial suppression of the $\mathrm{XO}$ activity and ROS generation during the early stage of cells growth protects the culture, whereas at the late stages, possibly, activity of the same enzyme and formed products trigger more effective cell development, axonal and dendritic ends outgrowth, formation of the synapses and differentiation.

Further experiments are necessary for detailed delineation of the above-mentioned phenomena.
Acknowledgment. We are thankful to BS student Shushan Alaverdyan for her help during the work. Experiments and the entire work were performed on the basis of ANSEF-2381 AWARD support. Also, we are thankful to Prof R. A. Abramyan for the providing of the biological material.

\section{К. Е. Даніелян, Г. А. Кеворкян}

Активність ксантиноксидази регулює ріст клітин мозку ембріона людини

Резюме

Мета. Важливість функиіонування ксантиноксидази (КО) в процесах проліферації диференціації клітин доведено багатьма вченими. Ми припустили, щя КО виконує незамінну роль у процесах розвитку, дозрівання, а також загибелі клітин мозку ембріона людини. Методи. Абортивний матеріал людини застосовано для культивування клітин (Е90). Активність КО визначали за кількістю сечової кислоти в тканині; клітинну смерть - з використанням трипанового синього. Результати. Алопуринол, згідно із нашим дослідженням, пригнічує активність КО (0,12 $\pm 0,02 ; 0,20 \pm$ $\pm 0,03$ відповідно, $p \leq 0,05)$. На 12-й день кількість клітин у культурі, у яку вносили алопуринол, починаючи з перших етапів розвитку, була вищою, ніж у контролі $(2350,1 \pm 199,0$ vs $2123 \pm 96)$, та перевищувала кількість клітин у культурі, до якої додавали алопуринол на більш пізніх стадіях росту і розвитку $(1479,6 \pm$ $\pm 103,8, p<0,05)$. В усіх культурах кількість мертвих клітин виявилася нижчою порівняно з контролем, що вказує на захисні властивості алопуринолу як інгібітора КО. Висновки. Алопуринол ініціює клітинну проліферацію на ранніх етапах розвитку клітинної куль тури та пригнічує клітинний ріст на пізніших стадіях.

Ключові слова: ксантиноксидаза, ембріональні клітини мозку людини, проліферація, клітинна смерть.

\section{К. Э. Даниелян, Г. А. Кеворкян}

Активность ксантиноксидазы регулирует рост клеток мозга эмбриона человека

Резюме

Цель. Важность функиионирования ксантиноксидазы (КО) в прочессах пролиферачии и дифференциации клеток доказана рядом ученых. Мы предположили, что КО выполняет незаменимую роль в процессах развития, созревания, а также смерти клеток мозга эмбриона человек. Методы. Человеческий абортивный материал применен для культивирования клеток (Е90). Активность КО определяли по количеству мочевой кислоты в ткани; клеточную смерть - с использованием трипанового синего. Результаmbl. Аллопуринол, согласно нашим исследованиям, подавляет активность КО $(0,12 \pm 0,02 ; 0,20 \pm 0,03$ соответственно, $p \leq 0,05)$. На 12-й день количество клеток в культуре, в которую вносили аллопуринол, начиная с первых этапов развития, было выме, чем в контроле (2350,1 $\pm 199,0$ vs $2123 \pm 96)$, и превышало количество клеток в культуре, в которую добавляли аллопуринол на более поздних стадиях роста и развития $(1479,6 \pm 103,8, p<0,05)$. Во всех культурах количество мертвых клеток оказалось ниже, чем $в$ контроле, что указывает на защитные свойства аллопуринола как ингибитора КО. Выводы. Аллопуринол инициирует клеточ- 

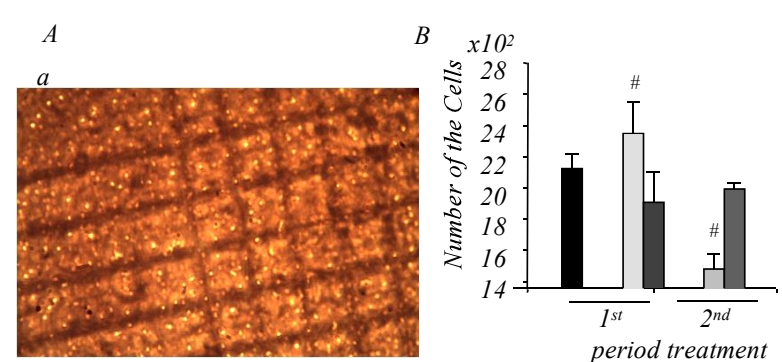

$b$

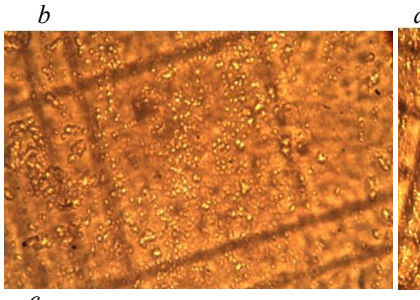

$d$
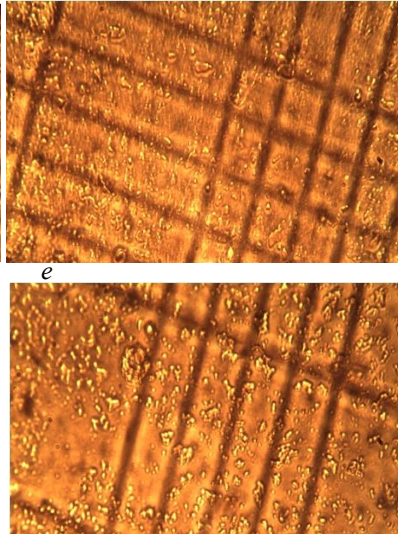

Fig. 2. The influence of Allopurinol on the cell number at day $12^{\text {th }}$. magnification $60 \times 1.25 \times 20$. The first group of the cells was treated during the entire period of the culturing, from day $1^{\text {st }}$ until the day $12^{\text {th }}(b, c)$, whereas the second group was treated during the second period, which was starting from day $6^{\text {th }}$ until day $12^{\text {th }}(d, e)$. Also, it was used t-student test to calculate the significance of the results. Results were considered significant, if $\mathrm{p}<0.05$. The results related with the low concentration of Allopurinol in comparison with each other and Control $(a)$ were statistically significant

Figure to article D. O. Gudkova et al.
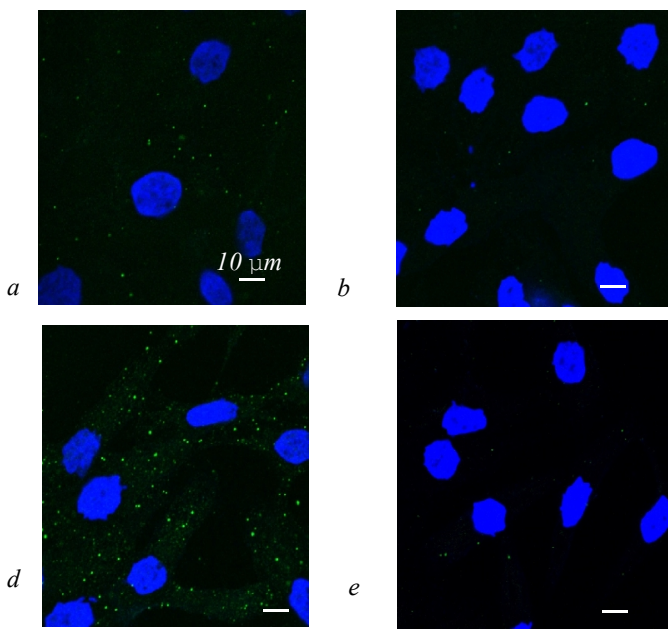
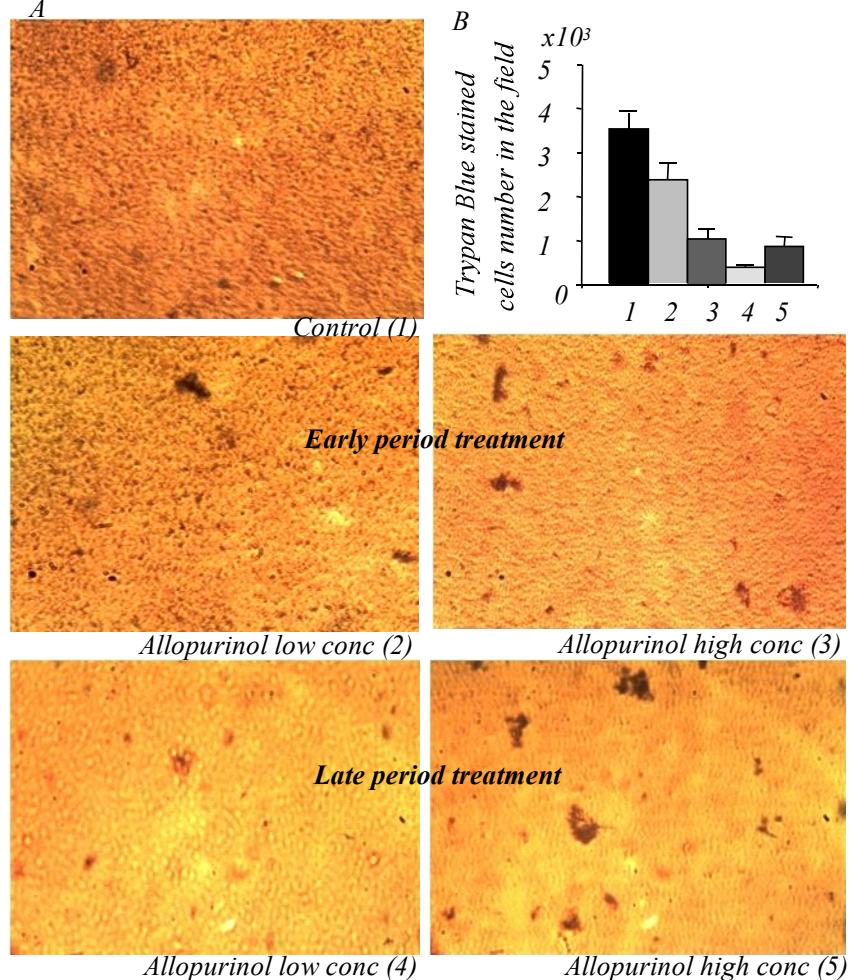

ith

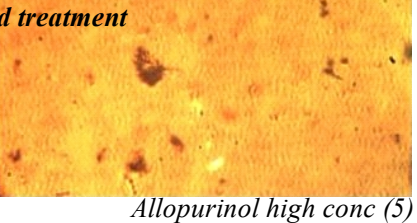

Fig. 3. The number of dead cells in the field, stained with the Trypan Blue $\mathrm{c}$ on $12^{\text {th }}$ day after seeding human embryonic neuronal cells. Magnification $60 \times 1.25 \times 20$. The pictures were taken on day $12^{\text {th }}(A)$. There were calculated results of the observation of 3 different fields from the plates for every group $(B)$. The first column represents the control group. The second column represents the cells treated with low, the thirdwith high concentrations of Allopurinol reflecting the conditions when the cells in the culture were receiving the Allopurinol from day $1^{\text {st }}$ to day $12^{\text {th }} .4^{\text {th }}$ and $5^{\text {th }}$ columns represent the group of the cells receiving the low and hight concentrations of Allopurinol from day $6^{\text {th }}$ to day $12^{\text {th }}$. The results were accepted as a statistically significant when $\mathrm{p}<0.05$

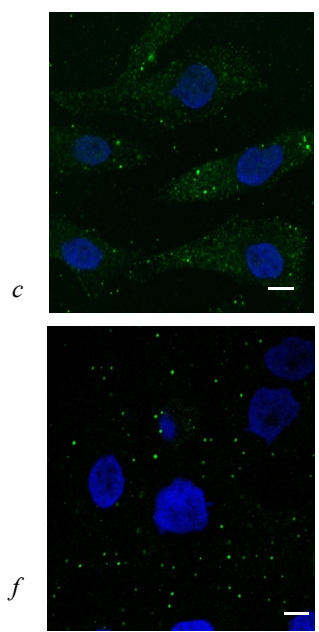

Fig..1. HEK293 cells were treated with rapamycin (b), LY294002 (c), 2-deoxyglucose (d), $\mathrm{CHX}(e)$ and sodium arsenite $(f)$ during $30 \mathrm{~min}$. Picture $a$ represent cells treated with DMSO. After treatment cells were fixed with $3.7 \%$ FA, and stained with anti-RCD-8 antibodies. As secondary were used FITC-conjugated antibodies. Cell nuclei were stained with Hoechst 33258. Magnification $\times 100$ 
ную пролиферациию на ранних этапах развития клеточной культуры и подавляет клеточный рост на более поздних стадиях.

Ключевые слова: ксантиноксидаза, эмбриональные клетки мозга человека, пролиферация, клеточная смерть.

\section{REFERENCES}

1. Blaschke A. J., Staley K., Chun J. Widespread programmed cell death in proliferative and postmitotic regions of the fetal cerebral cortex // Development.-1996.-122, N 4.-P. 1165-1174.

2. Hughes W. F., McLoon S. C. Ganglion cell death during normal retinal development in the chick: comparisons with cell death induced by early target field destruction // Exp. Neurol.-1979.66, N 3.-P. 587-601.

3. Clarke P. G., Rogers L. A., Cowan W. M. The time of origin and the pattern of survival of neurons in the isthmo-optic nucleus of the chick // J. Comp. Neurol.-1976.-167, N 2.-P. 125-142.

4. Moriwaki Y., Yamamoto T., Higashino K. Enzymes involved in purine metabolism - a review of histochemical localization and functional implications // Histol. Histopathol.-1999.-14, N 4.P. 1321-1340.

5. Khalil Z., Khodr B. A role for free radicals and nitric oxide in delayed recovery in aged rats with chronic constriction nerve injury // Free Radic. Biol. Med.-2001.-31, N 4.-P. 430-439.
6. Tennant $J$. R. Evaluation of the trypan blue technique for determination of cell viability // Transplantation.-1964.-2.P. 685-694.

7. Rahman A., Katzive L., Henshaw S. K. A Global review of laws on induced abortion, 1985-1997 // Int. Fam. Plann. Persp.1998.-24, N 2.- P. 56-64.

8. Mattson M. P., Rychlik B. Cell culture of cryopreserved human fetal cerebral cortical and hippocampal neurons: neuronal development and responses to trophic factors // Brain Res.1990.-522, N 2.-P. 204-214.

9. Litwack G., Bothwell J. W., Williams J. N. Jr., Elvehjem C. A. A colorimetric assay for xanthine oxidase in rat liver homogenates // J. Biol. Chem.-1953.-200, N 1.-P. 303-310.

10. Kruger N. J. The Bradford method for protein quantitation // Methods Mol. Biol.-1994.-32.-P. 9-15.

11. Fatokun A. A., Stone T. W., Smith R. A. Hydrogen peroxide mediates damage by xanthine and xanthine oxidase in cerebellar granule neuronal cultures // Neurosci. Lett.-2007.-416, N 1.P. 34-38.

UDC 576.8.09729+612.42+547.582.3+661 Received 10.08.11 